\title{
Global burden of diarrheal disease attributable to the water supply and sanitation system in the State of Minas Gerais, Brazil: 2005
}

Andreia Ferreira de Oliveira ${ }^{1}$ Iuri da Costa Leite ${ }^{1}$ Joaquin Gonçalves Valente ${ }^{1}$

\footnotetext{
${ }^{1}$ Departamento de Epidemiologia e Métodos Quantitativos em Saúde, Fiocruz. R. Leopoldo Bulhões 1480/830, Manguinhos. 21041-210 Rio de Janeiro RJ Brasil andreiaf@globo.com
}

\begin{abstract}
Advances have occurred in relation to the coverage of water supply and sanitation in Brazil, however inequalities are still observed in relation to the coverage of these services, reflecting the importance of diarrheal disease in the Brazilian epidemiological context. The aim of this study was to measure the impact of the water supply and sanitation system on diarrheal diseases among children aged under five. The global burden of diarrhea was calculated based on the attributable population fraction, using information on prevalence and relative risks from the 2000/2010 censuses and a study by Pruss et al. The north of the State of Minas Gerais, the Northeast and Jequitinhonha regions had the highest disability-adjusted life year (DALY) rates and ratios. The fraction of diarrhea attributable to the water supply and sanitation system was $83 \%$, decreasing to $78.3 \%$ where sanitation had $100 \%$ coverage. An inverse relationship was found between DALY rates and attributable fractions and per capita GDP. Broadening the scope and coverage of services and improving the quality of water available in homes is an urgent requirement. These measures will bring economic and social benefits related to the reduction of diarrheal diseases and consequent improvement of the quality of life of children aged under five.
\end{abstract}

Key words Sanitation, Water, Diarrhea, Global burden, Disease 


\section{Introduction}

The impact of environmental risk factors on burden of disease studies has been measured in several regions of the Planet since $1990^{1}$, with updates and method advances available for $2001^{2}$, $2004^{3}$, and, more recently for $2010^{4}$.

Thirty-three percent of burden of disease (DALY) is attributable to environmental factors ${ }^{5}$. Despite its relevance, studies on burden of disease are scarce ${ }^{5,6}$. An environmental factor with a major impact on the health of populations is related to access to adequate sewage and water supply systems. The factor was included among the Millennium Development Goals (MDG) that established that the proportion of individuals without access to drinking water and to basic sanitation should be reduced in 50\% between 1990 and $2015^{7,8}$.

According to a survey performed by the WHO, investments to improve water supply, sanitation and hygiene in all countries could prevent a series of health disorders, especially diarrhea that has an approximate $9.1 \%$ impact on the global burden of disease and a $6.3 \%$ impact on total deaths, mainly among children up to the age of five?.

Diarrhea is considered a public health concern, given its universal occurrence and because it affects individuals of all ages and social classes ${ }^{10}$. Diarrhea is considered one of the major causes of morbidity and mortality in developing countries $^{11,12}$, especially among children under five $\mathrm{e}^{13-17}$ who live in unfavorable sanitary conditions ${ }^{18,19}$. Reflecting this inequality, diarrheal diseases were responsible for $4.8 \%$ of global burden of disease, and $7.2 \%$ in developing countries. According to a Unicef and WHO report ${ }^{20}$, the proportion of the population with access to improvements in sanitation grew from $68 \%$ to $79 \%$ between 1990 and 2010 in Brazil. Progress has also been observed in relation to use of drinking water: $89 \%$ to $98 \%$. Despite the growth, there are still inequalities related to the coverage of these services among regions and social groups in the country, which would possibly explain the importance of diarrheal diseases in the Brazilian scenario.

A study on Burden of Disease in the State of Minas Gerais for $2005^{21}$ showed that social inequality has an important role in the State, given that higher standardized DALY rates were observed in the poorest macro regions of the State: Norte de Minas, Nordeste and Jequitinhonha. Bearing this scenario in mind, the present study aims to measure the impact of water sup- ply and the sanitation system on diarrheal diseases among children under the age of five, in the State of Minas Gerais and its 13 macro-regions in 2005 .

\section{Methods}

Information on burden of disease attributable to diarrhea for the State of Minas Gerais and its 13 macro health regions was obtained from a study performed by Leite et al. ${ }^{21}$ using 2005 as reference year. Studies on burden of disease use DALY (disability-adjusted life years) to measure health status of populations ${ }^{1,22}$. DALY is a synthetic indicator that measures the impact of mortality and morbidity simultaneously. Thus, DALY is calculated as the sum of two components: YLL (years of life lost) and YLD (years of life lost due to disability). DALY was calculated per gender, age group for over 100 diseases/disorders, including diarrhea for the burden of disease study in Minas Gerais.

The burden of diarrhea attributable to water supply and sanitation was calculated based on the population attributable fraction (PAF), which has been widely used in epidemiological studies, to measure how much of a burden of disease could be avoided, if any risk exposure factor for the occurrence of a certain disease were hypothetically eliminated. PAF is defined as the amount or proportion of burden of disease, in the population, attributable to a certain exposure factor, in which: pi is the prevalence of exposure category $i$ of the risk factor and $\mathrm{RRi}$ is the relative risk calculated in relation to the reference exposure category.

$$
\mathrm{FPA}=\frac{\sum_{i=1}^{k} p_{i}\left(R R_{i}-1\right)}{1+\sum_{i=1}^{k} p_{i}\left(R R_{i}-1\right)}=1-\frac{1}{\sum_{i=1}^{k} p_{i}\left(R R_{i}-1\right)}
$$

In which: $p_{i}$ is the prevalence of exposure category $\mathrm{i}$ of the risk factor and $R R_{i}$ is the relative risk calculated in relation to the reference exposure category.

\section{Prevalence of categories of exposure to risk factor}

Information on the prevalence of exposure to the water supply and sanitation system categories, 
representative of the health macro regions of the state of Minas Gerais, are available in the 2000 and 2010 censuses $^{23,24}$.

The Joint Monitoring Programme (JMP) is an official structure of the United Nations responsible for the development of indicators aimed at monitoring access of the population to water supply and sanitation for the World and regions $^{25}$. The program has defined a set of criteria to classify the adequacy of both the basic sanitation and the water supply systems (Table 1 ). Not all criteria established by the JMP for water supply and sanitation can be used in Brazil. The definitions have a high level of detail that was not incorporated into any of the two censuses, and therefore require making the information compatible.

The current scenarios based on adapting the definition to water supply and sewage, according to the information available in the 2000, 2010 Censuses and JMP were the following: Adequate water supply: home or land connected to: 1) general water system; 2 ) well or spring on the land or property; 3 ) rainwater cistern storage system.

Inadequate water supply: home or land with water supply other than the one stated previously. Adequate sanitary sewage: home with bathroom or latrine connected to: 1) public sewer or rainwater network; 2) septic system.
Inadequate sanitary sewage: 1) home with bathroom or latrine connected to another system not previously mentioned; 2) home without a bathroom or latrine. The categories of the sanitary sewage variable used in the definition of adequacy criteria proposed by the JMP, were available in the 2000 and 2010 censuses and, thus, the prevalence rates of exposures related to sanitary sewage were calculated directly.

The water supply system categories, however, were different and required a slight adjustment. In the 2000 Census, water supply was only measured as the presence of a general system, well or spring at the household. However, according to the JMP definition, adequate water supply should include the presence of a cistern as a means of storing rainwater. Given this response category was only present in the 2010 Census, the percentage in the response category "other" of the variable water supply of the 2000 census was used to define the number of dwellers in private permanent households that had a cistern in 2000.

After making the information on the sewage and water supply system of the 2000 and 2010 censuses compatible, the prevalence for each one of the four exposure categories to the risk factor, for the State of Minas Gerais and its 13 health macro regions was estimated for 2005, based on the geometric rate of population growth in the inter-census period.

Table 1. Adequacy criteria of sanitation and water supply systems defined by the JMP.

\begin{tabular}{|c|c|c|}
\hline & Water supply & Sanitation $^{*}$ \\
\hline \multirow[t]{6}{*}{ Adequate } & Household land or yard piped water connection & Drainage to: piped sewer system \\
\hline & Public faucet/fountains & Septic system \\
\hline & Well with pipe & Latrine \\
\hline & Protected excavated well & Improved ventilated latrine \\
\hline & Protected reservoir & Protected latrine \\
\hline & Rainwater collector & Waste composting bathroom \\
\hline \multirow[t]{6}{*}{ Inadequate } & Unprotected excavated well & Drainage without an established \\
\hline & Unprotected reservoir & route $^{* *}$ \\
\hline & Vehicle with small tank/container & Unprotected or open latrine \\
\hline & Bottled water ${ }^{* * *}$ & Pail \\
\hline & Tanker truck & Bathroom or suspended latrine \\
\hline & Surface water (rivers, channels, etc.) & No facilities, woods or field \\
\hline
\end{tabular}

Source: WHO, 200725. * Only facilities that are not shared or are not public are considered improvements. ${ }^{* *}$ Excreta thrown on streets, yard or land; open air sewage, pit. ${ }^{* * *}$ Improvement is considered only when the household uses water from an "improved" source for cooking and personal hygiene. 


\section{Relative Risks for risk factor exposure categories}

Relative risks were obtained from a study performed by Pruss et al. ${ }^{14}$, in which the burden of disease associated with inadequate water, sanitation and hygiene was estimated for the world and geographic regions. The study presents exposure scenarios for the population and their relative risks according to two criteria: minimum and realistic. The minimum criterion has more conservative estimates and takes into account only personal hygiene. The realistic criterion, on the other hand, takes into account the quality of the water supply (by improvement of drinking water at points of use), in addition to hygiene.

The relative risks used to calculate PAF were based on an ideal scenario, in which there is no transmission of diarrheal diseases by inadequate water, sanitation or hygiene ${ }^{14}$. Relative risks were the following: ideal scenario ( $R R=1$ ); Presence of water and sanitation $(\mathrm{RR}=4.5)$; Absence of water and presence of sanitation $(R R=6.9)$; Presence of water and absence of sanitation $(\mathrm{RR}=8.7)$ and Absence of water and sanitation $(R R=11.0)$.

\section{Calculation of Population Attributable Fractions}

Attributable fractions were calculated based on three existing scenarios: the first measured the impact of the four exposure categories. In the second, the assumption was that all households had adequate water available. For the last one, all households were considered as having adequate water and sanitation. PAFs were then applied in the total DALY from diarrhea in the State of Minas Gerais and macro regions, for the year 2005. In this way, total DALY from diarrhea attributable to water supply and sanitation system was obtained.

\section{Results}

Table 2 shows the prevalence in children under the age of five according to adequacy criterion for water supply and sanitary sewage. The highest prevalence rates of simultaneously inadequate water supply and sanitary sewage systems were found in the Jequitinhonha (13.6\%), Norte de Minas (13.4\%) and Nordeste (11.6\%) macro regions. The same regions also had the lowest prevalence of both systems simultaneously adequate.
Table 3 shows the DALY rates and rate ratios due to diarrhea among children under five, according to: gender, age groups ( $<1$ year, 1 to 4 years) and macro regions of the State of Minas Gerais.

Total DALY rates were higher in the Nordeste, Jequitinhonha and Norte de Minas macro regions, with DALY rates, approximately $138 \%$, $42 \%$ and $27 \%$ respectively higher than the rate for the State of Minas Gerais. These macro regions also had the highest DALY rates from diarrhea, although the Norte de Minas macro region ranked second, with a DALY rate from diarrhea around 14.1 per 1,000 children, roughly $123 \%$ higher than the mean for the state as a whole. Although total and diarrhea DALY rates were higher among children under 1 year of age, the regional pattern was similar. It is important to underscore that the Nordeste, Jequitinhonha and Norte de Minas macro regions are the most economically unfavorable regions of the state.

Regarding attributable population rates (Table 4), calculated based on four exposure categories, figures over $80 \%$ in all macro regions of the State of Minas Gerais were observed. The highest population attributable fractions were observed in the three most vulnerable macro regions of the state: Norte de Minas, Jequitinhonha and Nordeste.

Table 2. Prevalence of children under the age of five, living in private permanent households according to adequacy of water supply and of sanitary sewage. Minas Gerais and macro regions, 2005.

\begin{tabular}{lrccc}
\hline \multirow{2}{*}{\multicolumn{1}{c}{ Region }} & \multicolumn{4}{c}{ Adequate water } \\
\cline { 2 - 5 } & \multicolumn{3}{c}{ No } & \multicolumn{2}{c}{ Yes } \\
\cline { 2 - 5 } & \multicolumn{4}{c}{ Adequate Sanitation } \\
\cline { 2 - 5 } & No & Yes & No & Yes \\
\hline Minas Gerais & $\mathbf{4 . 0}$ & $\mathbf{0 . 6}$ & $\mathbf{2 6 . 0}$ & $\mathbf{6 9 . 4}$ \\
Jequitinhonha & 13.6 & 0.4 & 47.3 & 38.7 \\
Norte de Minas & 13.4 & 0.5 & 57.2 & 28.8 \\
Nordeste & 11.6 & 0.9 & 46.4 & 41.0 \\
Leste do Sul & 4.3 & 0.8 & 37.3 & 57.6 \\
Noroeste & 3.9 & 0.3 & 32.7 & 63.0 \\
Centro Sul & 3.6 & 0.7 & 25.7 & 70.0 \\
Leste & 3.0 & 0.9 & 26.2 & 69.9 \\
Sul & 2.7 & 0.7 & 16.9 & 79.6 \\
Sudeste & 2.2 & 1.0 & 19.8 & 77.1 \\
Centro & 1.8 & 0.4 & 20.8 & 77.0 \\
Oeste & 1.1 & 0.4 & 18.2 & 80.3 \\
Triângulo do Sul & 0.9 & 0.3 & 11.4 & 87.4 \\
Triângulo do Norte & 0.9 & 0.2 & 11.0 & 87.8 \\
\hline
\end{tabular}

Source: IBGE, 2000/2010 Census ${ }^{23,24}$. 
Table 3. DALY rates and rate ratios (all causes and from diarrhea) for children under the age of five, according to age group and health macro regions. Minas Gerais, 2005.

\begin{tabular}{|c|c|c|c|c|c|c|c|c|c|c|c|c|}
\hline \multirow{3}{*}{ Macro region } & \multicolumn{6}{|c|}{ All Causes } & \multicolumn{6}{|c|}{ Diarrheas } \\
\hline & \multicolumn{3}{|c|}{ DALY $(1,000)$} & \multicolumn{3}{|c|}{ Ratio $^{*}$} & \multicolumn{3}{|c|}{ DALY $(1,000)$} & \multicolumn{3}{|c|}{ Ratio $^{*}$} \\
\hline & Total & $<1$ & $1-4$ & Total & $<1$ & $1-4$ & Total & $<1$ & $1-4$ & Total & $<1$ & $1-4$ \\
\hline Minas Gerais & 163 & 658 & 44 & 100 & 100 & 100 & 6 & 15 & 4 & 100 & 100 & 100 \\
\hline Nordeste & 388 & 1679 & 73 & 238 & 255 & 168 & 24 & 79 & 11 & 381 & 524 & 255 \\
\hline Norte de Minas & 208 & 853 & 53 & 127 & 130 & 122 & 14 & 30 & 10 & 223 & 200 & 243 \\
\hline Jequitinhonha & 232 & 990 & 55 & 142 & 151 & 126 & 11 & 25 & 7 & 166 & 167 & 169 \\
\hline Leste do Sul & 167 & 645 & 48 & 102 & 98 & 109 & 8 & 19 & 5 & 121 & 125 & 116 \\
\hline Noroeste & 145 & 574 & 42 & 89 & 87 & 97 & 7 & 17 & 4 & 105 & 114 & 98 \\
\hline Leste & 176 & 709 & 47 & 108 & 108 & 109 & 6 & 15 & 4 & 98 & 96 & 99 \\
\hline Sudeste & 162 & 675 & 39 & 100 & 103 & 90 & 6 & 15 & 3 & 89 & 99 & 81 \\
\hline Centro-Sul & 168 & 704 & 42 & 103 & 107 & 96 & 5 & 13 & 3 & 79 & 83 & 77 \\
\hline Oeste & 140 & 567 & 38 & 86 & 86 & 87 & 4 & 7 & 3 & 63 & 48 & 76 \\
\hline Triângulo do Sul & 141 & 559 & 41 & 87 & 85 & 93 & 4 & 8 & 3 & 62 & 54 & 68 \\
\hline Centro & 135 & 521 & 40 & 83 & 79 & 92 & 4 & 7 & 3 & 55 & 47 & 61 \\
\hline Sul & 128 & 512 & 36 & 78 & 78 & 83 & 4 & 6 & 3 & 55 & 38 & 70 \\
\hline
\end{tabular}

Source: Núcleo de estudo e métodos aplicados ao estudo de Carga de Doença - ENSP/Fiocruz.

Table 4. Attributable Fractions (\%) and DALY rates from diarrhea among children under the age of five, attributable to water supply system and sanitation according to macro regions. Minas Gerais, 2005.

\begin{tabular}{|c|c|c|c|c|c|c|}
\hline \multirow[t]{2}{*}{ Macro region } & \multirow[b]{2}{*}{$\mathrm{FA}^{*}$} & \multicolumn{2}{|c|}{ Water for all ${ }^{* *}$} & \multicolumn{2}{|c|}{ Sanitation for all ${ }^{* * *}$} & \multirow{2}{*}{$\begin{array}{c}\text { DALY } \\
\text { from diarrhea } \\
\text { (per } 1,000 \text { inhab.) }\end{array}$} \\
\hline & & Proportion & Variation \% & Proportion & Variation \% & \\
\hline Minas Gerais & 83.0 & 82.6 & 99.5 & 78.3 & 94.7 & 5.2 \\
\hline Norte de Minas & 87.2 & 86.6 & 99.3 & 79.3 & 91.5 & 12.3 \\
\hline Jequitinhonha & 86.5 & 85.8 & 99.1 & 79.3 & 92.4 & 9.1 \\
\hline Nordeste & 86.2 & 85.6 & 99.3 & 79.2 & 92.5 & 20.8 \\
\hline Leste do Sul & 84.3 & 84.0 & 99.6 & 78.4 & 93.3 & 6.5 \\
\hline Noroeste & 83.7 & 83.4 & 99.6 & 78.3 & 93.8 & 5.6 \\
\hline Centro Sul & 82.9 & 82.6 & 99.6 & 78.3 & 94.7 & 4.2 \\
\hline Leste & 82.8 & 82.5 & 99.6 & 78.2 & 94.7 & 5.1 \\
\hline Centro & 81.8 & 81.6 & 99.7 & 78.0 & 95.5 & 2.8 \\
\hline Sudeste & 81.8 & 81.6 & 99.7 & 78.1 & 95.7 & 4.6 \\
\hline Sul & 81.5 & 81.2 & 99.6 & 78.2 & 96.3 & 2.8 \\
\hline Oeste & 81.3 & 81.2 & 99.8 & 78.0 & 96.0 & 3.2 \\
\hline Triângulo do Sul & 80.2 & 80.1 & 99.8 & 77.9 & 97.2 & 3.1 \\
\hline Triângulo do norte & 80.1 & 80.0 & 99.8 & 77.9 & 97.3 & 2.2 \\
\hline
\end{tabular}

Source: Núcleo de estudo e métodos aplicados ao estudo de Carga de Doença - ENSP/Fiocruz. * AF calculated for 4 scenarios, together. ${ }^{* *} \mathrm{AF}$ calculated reallocating prevalence rates in 2 scenarios: Absence of water /sanitation; Presence of water and sanitation. ${ }^{* * *}$ AF calculated reallocating prevalence rates in 2 scenarios: Absence of water /Presence of sanitation; Presence of water and sanitation.

Considering the assumption that all households would have access to adequate water, there would be a very small reduction in attributable fractions. If there were complete access to basic sanitation available to all households, reductions would be more expressive.
The highest reduction in attributable fractions, therefore, observed a hypothetical scenario, in which basic sanitation would be available to all. In this scenario, $78.3 \%$ of diarrhea would be attributable to water supply and sanitation system. The percentages would range 
between $77.9 \%$, in the Triângulo do Norte, and $79.3 \%$, in the Norte de Minas macro-regions. Regarding the occurrence of diarrhea attributable to water supply and basic sanitation, the highest DALY rates were found in the most economically unfavorable macro regions: Nordeste $(20.8 / 1,000$ inhabitants), Norte de Minas (12.3/1,000 inhabitants) and Jequitinhonha (9.1/1,000 inhabitants).

There was an inverse correlation between population attributable fractions and per capita GDP, and DALY rates and per capita GDP in the state and macro regions in 2005. So, the highest attributable fractions and DALY rates were found in areas with the lowest per capita GDP (Figure 1).
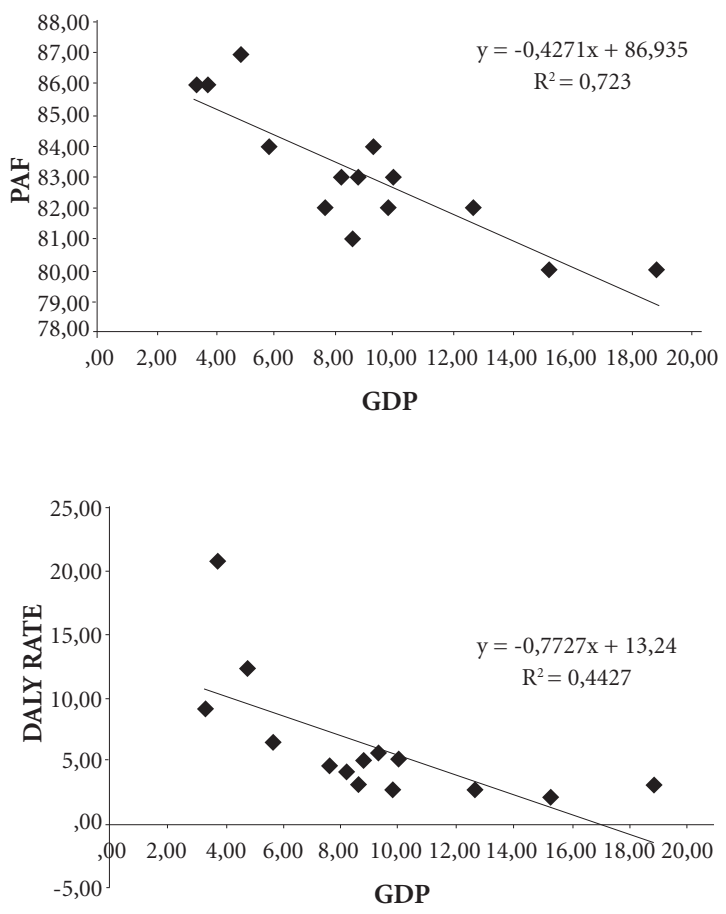

Figure 1. Population Attributable Fractions (\%) and DALY rates from diarrhea among children under the age of five attributable to water supply system and sanitation according to per capita GDP and macro regions. Minas Gerais, 2005.

Source: Núcleo de estudo e métodos aplicados ao estudo de Carga de Doença - ENSP/Fiocruz.

\section{Discussion and final comments}

Due to changes in the PAF estimation process, mainly because of the inclusion of new diseases, the results of the present study were compared to the results in which only diarrhea was taken into account as a condition associated with inadequate water, sanitation and hygiene.

Among the major results found in the study, the highest DALY rates (all causes and specifically from diarrhea) and DALY rate ratios were found in the most economically unfavorable regions of the State: Norte de Minas, Nordeste and Jequitinhonha. Moreover, the fraction of diarrhea attributable to water supply and sanitation in the State as a whole was $83.0 \%$, and it would fall to $78.3 \%$ if the sanitation coverage were $100 \%$ in the State. An inverse correlation was found between DALY rates and per capita GDP, and between attributable fractions and per capita GDP in the State, and in the macro regions of Minas Gerais.

In 2001, Rodgers et al. ${ }^{26}$ estimated that 3.7\% of total DALY anticipated for all countries could be attributed to the inadequate water, sanitation and hygiene factor, and that $5.5 \%$ and $1.8 \%$ of total DALY, respectively, would be attributable to the study factor in countries with high and low mortality rates. Among children under four years, the percentage was $9 \%$ of total DALY ${ }^{27}$.

In the present study, $3.2 \%$ of total DALY in the State of Minas Gerais was attributed to water supply and sanitation among children under the age of five, reaching 5.9\% in the Norte de Minas macro region.

Unlike what was found in the present study, a 2004 WHO report ${ }^{3}$ showed that inadequate water, sanitation and hygiene are responsible for $6.3 \%$ and $4.2 \%$ of total DALY for low income countries and all countries in the world, respectively.

Pruss-Ustun et al. $^{27}$ observed that the fraction of diarrhea attributable to inadequate water, sanitation and hygiene in children in developing countries ranged between 85 and 90\%. The figure was $87 \%$ for Latin America and the Caribbean ${ }^{22}$.

In the present study, the figure found among under five year-olds was $83 \%$ for the State of Minas Gerais, reaching $87 \%$ in the Norte de Minas macro region.

The inverse correlation found in the present study between DALY and per capita GDP was also observed in a study that evaluated regional discrepancies in burden of disease attributable to inadequate water, sanitation and hygiene in China $^{28}$. 
Although the association between diarrhea and basic sanitation has been well established, there are few studies on the effectiveness of sanitation-oriented interventions in the prevention of the disease. Moreover, most of the evidence results from observational studies ${ }^{29-31}$.

Among the limitations appointed by studies that worked with water, sanitation and hygiene associated with diarrhea, we emphasize: 1) Lack of control of bias and confounders ${ }^{32-34}$; 2) Limitations related to exclusion of studies in Chinese ${ }^{17}$.

Recently, systematic revisions and meta-analyses that evaluated interventions oriented toward hand washing ${ }^{12}$, disposal of human excreta ${ }^{34}$ and quality of water ${ }^{35,36}$ in the prevention of diarrhea have been published. These studies have observed an ample variation in estimate of measurements of effect due to substantial heterogeneity in type of design and intervention, and therefore do not allow for the calculation of combined effects. The exception was for hygiene-oriented interventions, in which summary measurements were calculated, including the percentage of reduction in episodes of diarrhea ${ }^{12}$.

Among the major limitations of the present study, we can mention that the definitions and relative risks used to calculate fractions attributable to water supply and sanitation did not consider hygiene. Although the subject was incorporated into some scenarios used by Pruss et al. ${ }^{14}$, the information was not used in the present study, given the absence of population data compatible with the Brazilian scenario. Moreover, relative risks were built for the under five years of age Brazilian scenario using an external population, between 3 and 36 months of age. Another issue relates to the information on water supply available in the Censuses. The JMP works with the inclusion of other variables in the definition of adequate water and, if the information were available for Brazil, we could have qualified the data better and consequently attained more accurate information on the scenario. Another point to emphasize is the lack of information available on the quality of water in major databases. The monitoring of factors that affect the quality of water offered is related to infra-structure issues (cleaning of pipes, supply interruptions) and should be important variables for estimating parameters.

These limitations are believed to have contributed to the conservative estimates of the parameters in the present study.

The process of urbanization and growth in population density in large cities has brought about the need for adequate quantity and quality of water supply and of collection and treatment of human excreta in Brazil, like in most Latin American countries. However, the urban population has been acquiring access to water through a perilous expansion, above the capacity of supply systems, without promoting collection and treatment of sewage and garbage. The combination of universalization of access to water supply systems and of the growing vulnerability of superficial and underground sources has expanded health risks due to precarious systems, with growth in the population exposed to chemical and biological agents ${ }^{37}$.

More than coverage, vulnerable and intermittent water supply systems have been appointed as relevant problems in large cities ${ }^{38-40}$ because they allow for the intrusion of pathogenic agents through water contaminated in the distribution system $^{41}$.

Available piped water in households also has been appointed as an important factor to control diarrhea. The presence of piped water makes adequate personal, domestic and food hygiene possible, interrupting the oral-fecal transmission cycle of pathogens ${ }^{18}$.

According to data from PNAD 2005, in the State of Minas Gerais, $98.1 \%$ of the individuals that have piped water in at least one room also live in a home connected to the general distribution system. This information was taken into account to define scenarios and their associated relative risks.

Data from the PNDS $2006^{42}$ show that the quality and quantity of water available to the population in Brazil has not improved in recent years and that the population began to use more bottled water due to the quality of the water from the general system, wells and springs.

Monitoring the quality of the water offered, by evaluating its accessibility, availability (amount, reliability, continuity) and acceptability, and monitoring an effective sanitation system to prevent exposure to fecal matter (appropriate treatment) may allow for potential gains to health in Brazil ${ }^{43-45}$. However, the challenge represented by the restricted availability of information in major databases has to be overcome $\mathrm{e}^{39,46,47}$.

In the State of Minas Gerais, in 2005, the percentage of children under five years of age, who live in households with adequate water and sanitation, was $69.4 \%$. Moreover, the high rates of total DALY and DALY from diarrhea, mainly in economically unfavorable regions of the state, showed the need for expansion of services cover- 
age and improvement in the quality of water and in the sanitation system.

These measures and mainly those related to the reduction in diarrheal diseases, bring about economic and social benefits to the entire population, and consequently improve the quality of life and reduce health expenditures.

\section{Collaborators}

AF Oliveira, IC Leite and JG Valente participated equally of all stages of preparation of the manuscript. 


\section{References}

1. Murray CJ, Lopez AD. Global Health Statistics: A Compendium of Incidence, Prevalence and Mortality Estimates for over 200 conditions. Geneva: WHO; 1996.

2. World Health Organization (WHO). The World Health Report 2002: Reducing Risks, Promoting Healthy Life. Geneva: WHO; 2002.

3. World Health Organization (WHO). Global health risks: mortality and burden of disease attributable to selected major risks. Geneva: WHO; 2009.

4. Lim SS1, Vos T, Flaxman AD, Danaei G, Shibuya K, Adair-Rohani H, Amann M, Anderson HR, Andrews KG, Aryee M, Atkinson C, Bacchus LJ, Bahalim AN Balakrishnan K, Balmes J, Barker-Collo S, Baxter A, Bell ML, Blore JD, Blyth F, Bonner C, Borges G, Bourne R, Boussinesq M, Brauer M, Brooks P, Bruce NG, Brunekreef B, Bryan-Hancock C, Bucello C, Buchbinder R, Bull F, Burnett RT, Byers TE, Calabria B, Carapetis J, Carnahan E, Chafe Z, Charlson F, Chen H, Chen JS, Cheng AT, Child JC, Cohen A, Colson KE, Cowie BC, Darby S, Darling S, Davis A, Degenhardt L, Dentener F, Des Jarlais DC, Devries K, Dherani M, Ding EL, Dorsey ER, Driscoll T, Edmond K, Ali SE, Engell RE, Erwin PJ, Fahimi S, Falder G, Farzadfar F, Ferrari A, Finucane MM, Flaxman S, Fowkes FG, Freedman G, Freeman MK, Gakidou E, Ghosh S, Giovannucci E, Gmel G, Graham K, Grainger R, Grant B, Gunnell D, Gutierrez HR, Hall W, Hoek HW, Hogan A, Hosgood HD 3rd, Hoy D, Hu H, Hubbell BJ, Hutchings SJ, Ibeanusi SE, Jacklyn GL, Jasrasaria R, Jonas JB, Kan H, Kanis JA, Kassebaum N, Kawakami N, Khang YH, Khatibzadeh S, Khoo JP, Kok C, Laden F, Lalloo R, Lan Q, Lathlean T, Leasher JL, Leigh J, Li Y, Lin JK, Lipshultz SE, London S, Lozano R, Lu Y, Mak J, Malekzadeh R, Mallinger L, Marcenes W, March L, Marks R, Martin R, McGale P, McGrath J, Mehta S, Mensah GA, Merriman TR, Micha R, Michaud C, Mishra V, Mohd Hanafiah K, Mokdad AA, Morawska L, Mozaffarian D, Murphy T, Naghavi M, Neal B, Nelson PK, Nolla JM, Norman R, Olives C, Omer SB, Orchard J, Osborne R, Ostro B, Page A, Pandey KD, Parry CD, Passmore E, Patra J, Pearce N, Pelizzari PM, Petzold M, Phillips MR, Pope D, Pope CA 3rd, Powles J, Rao M, Razavi H, Rehfuess EA, Rehm JT, Ritz B, Rivara FP, Roberts T, Robinson C, Rodriguez-Portales JA, Romieu I, Room R, Rosenfeld LC, Roy A, Rushton L, Salomon JA, Sampson U, Sanchez-Riera L, Sanman E, Sapkota A, Seedat S, Shi P, Shield K, Shivakoti R, Singh GM, Sleet DA, Smith E, Smith KR, Stapelberg NJ, Steenland K, Stöckl H, Stovner LJ, Straif K, Straney L, Thurston GD, Tran JH, Van Dingenen R, van Donkelaar A, Veerman JL, Vijayakumar L, Weintraub R, Weissman MM, White RA, Whiteford $\mathrm{H}$, Wiersma ST, Wilkinson JD, Williams HC, Williams W, Wilson N, Woolf AD, Yip P, Zielinski JM, Lopez AD, Murray CJ, Ezzati M, AlMazroa MA, Memish ZA. A comparative risk assessment of burden of disease and injury attributable to 67 risk factors and risk factor clusters in 21 regions, 1990-2010: a systematic analysis for the Global Burden of Disease Study 2010. Lancet 2012; 380(9859):2224-2260.

5. Pruss-Ustun A, Bonjour S, Corvalán C. The impact of the environment on health by country: a meta-synthesis. Environ Health 2008; 7(7):1-10.
6. Pruss-Ustun A, Mathers C, Corvalán C, Woodward A. Introduction and Methods: assessing the environmental burden of disease at national and local levels. Geneva: World Health Organization (WHO); 2003. Environmental Burden of Disease Series, No 1.

7. Unicef, World Health Organization (WHO). Global Water Supply and Sanitation Assessment 2000 Report. Geneva: Unicef, WHO; 2000.

8. World Health Organization (WHO). Preventing disease through healthy environments. The contribution of water, sanitation and hygiene. Geneva: WHO; 2007.

9. Pruss-Ustun A, Bos R, Gore F, Bartram J. Safer water, better health: costs, benefits and sustainability of interventions to protect and promote health. Geneva: World Health Organization; 2008.

10. World Health Organization (WHO). The global burden of disease: 2004 update. Geneva: WHO; 2004.

11. Pruss-Ustun A, Corvalán C. Preventing disease through healthy environments: towards an estimate of the environmental burden of disease. Geneva: World Health Organization; 2008.

12. Ejemot RI, Ehiri JE, Meremikwu MM, Critchley JA. Hand washing for preventing diarrhoea. Cochrane $D a$ tabase Syst Rev 2012; (2):1-42.

13. Quick RE, Venczel LV, Mintz ED, Soleto L, Aparicio J, Gironaz M, Hutwagner L, Greene K, Bopp C, Maloney K, Chavez D, Sobsey M, Tauxe RV. Diarrhoea prevention in Bolivia through point-of-use water treatment and safe storage: a promising new strategy. Epidemiol Infect 1999; 122(1):83-90.

14. Prüss A, Kay D, Fewtrell L, Bartram J. Estimating the burden of disease from water, sanitation, and hygiene at a global level. Environ Health Perspect 2002; 110(5):537-542.

15. Guerrant RL, Kosek M, Moore S, Lorntz B, Brantley R, Lima AA. Magnitude and impact of diarrheal diseases. Arch Med Res 2002; 33(4):351-355.

16. Kosek M, Bern C, Guerrant RL. The global burden of diarrhoeal disease, as estimated from studies published between 1992 and 2000. Bull World Health Organ 2003; 81(3):197-204.

17. Fewtrell L, Kaufmann RB, Kay D, Enanoria W, Haller L, Colford JM Jr. Water, sanitation, and hygiene interventions to reduce diarrhea in less developed countries: a systematic review and meta-analysis. Lancet Infect Dis 2005; 5(1):42-52.

18. Silva GAP, Lira PIC, Lima MC. Fatores de risco para doença diarreica no lactente: um estudo caso controle. Cad Saude Publica 2004; 20(2):589-595.

19. Fink G, Gunther I, Hill K. The effect of water and sanitation on child health: evidence from the demographic and health surveys 1986-2007. Int J Epidemiol 2011; 40(5):1196-1204

20. Unicef, World Health Organization (WHO). Progress on drinking water and sanitation: 2012 update. Geneva: Unicef, WHO: 2012.

21. Leite IC, Valente JG, Schramm JMA. Carga Global de Doença do Estado de Minas Gerais, 2005. Relatório final. Rio de Janeiro: ENSP/Fiocruz/ENSPTEC; 2011. 
22. Ezzati M, Lopez AD, Rodgers A, Murray CJL. Comparative quantification of health risks: global and regional burden of disease attributable to select major risk factors. Geneva: World Health Organization (WHO); 2004.

23. Instituto Brasileiro de Geografia e Estatística (IBGE). Censo Demográfico 2000. Rio de Janeiro: IBGE; 2000.

24. Instituto Brasileiro de Geografia e Estatística (IBGE). Censo Demográfico 2010. Rio de Janeiro: IBGE; 2010.

25. World Health Organization (WHO), Unicef. Improved and unimproved water and sanitation facilities. [acessado 2015 jan 9]. Disponível em: http://www.wssinfo. org/definitions-methods/watsan-categories/

26. Rodgers A, Ezzati M, Vander Hoorn S, Lopez AD, Lin RB, Murray CJ; Comparative Risk Assessment Collaborating Group. Distribution of Major Health Risks: Findings from the Global Burden of Disease Study. Plos Med 2004; 1(1):44-55.

27. Pruss-Ustun A, Kay D, Fewtrell L, Bartram J. Unsafe water, sanitation and Hygiene. In: Ezzati M, Lopez AD, Rodgers A, Murray CJL. Comparative Quantification of Health Risks: Global and Regional Burden of Disease Attributable to Selected Major Risk Factors. Geneva: World Health Organization (WHO); 2004. vol 2. p. 1321-1352.

28. Carlton EJ, Liang S, McDowell JZ, Li H, Luo W, Remais JV. Regional disparities in the burden of disease attributable to unsafe water and poor sanitation in China. Bull World Health Organ 2012; 90(8):578-587.

29. Barreto ML, Genser B, Strina A, Teixeira MG, Assis AMO, Rego RF, Teles CA, Prado MS, Matos SMA, Santos DN, Santos LA, Cairncross S. Effect of city-wide sanitation programme on reduction in rate of childhood diarrhoea in northeast Brazil: assessment by two cohort studies. Lancet 2007; 370(10):1622-1628.

30. Genser B, Strina A, dos Santos LA, Teles CA, Prado MS, Cairncross S, Barreto ML. Impact of a city-wide sanitation intervention in a large urban centre on social, environmental and behavioural determinants of childhood diarrhoea: analysis of two cohort studies. Int $\mathrm{J}$ Epidemiol 2008; 37(4):831-840.

31. Green ST, Small MJ, Casman EA. Determinants of national diarrheal disease burden. Environ Sci Technol 2009; 43(4):993-999.

32. Esrey SA, Feachem RG, Hughes JM. Interventions for control of diarrhoeal diseases among young children: improving water supplies and excreta disposal facilities. Bull World Health Organ 1985; 63(4):757-772.

33. Esrey SA, Potash JB, Roberts L, Shiff C. Effects of improved water supply and sanitation on ascariasis, diarrhea, dracunculiasis, hookworm infection, schstomiasis, and trachoma. Bull World Health Organ 1991; 69(5):609-621.

34. Clasen TF, Bostoen K, Schmidt WP, Boisson S, Fung ICH, Jenkins MW, Scott B, Sugden S, Cairncross S. Interventions to improve disposal of human excreta for preventing diarrhea (review). Cochrane Database Syst Rev 2010; 6:1-31.

35. Clasen T, Schmidt WP, Rabie T, Roberts I, Cairncross S. Interventions to improve water quality for preventing diarrhoea: systematic review and meta-analysis. BMJ 2007; 334(7597):782.
36. Clasen TF, Roberts IG, Rabie T, Schmidt WP, Cairncross S. Interventions to improve water quality for preventing diarrhoea. Cochrane Database Syst Rev 2009; 3:1-116.

37. Andreazzi MAR, Barcellos C, Hacon S. Velhos indicadores para novos problemas: a relação entre saneamento e saúde. Rev Panam Salud Publica 2007; 22(3):211217.

38. Lee EJ, Schwab KJ. Deficiencies in drinking water distribution systems in developing coutries. J Water Health 2007; 3(2):109-127.

39. Unicef, World Health Organization (WHO). Drinking Water: Equity, safety and sustainability. Geneva: Unicef, WHO; 2011.

40. Hunter PR, MacDonald AM, Carter RC. Water Supply and Health. Plos Med 2010; 7(11):1-9.

41. Bartram J, Cairncross S. Hygiene, sanitation, and water: Forgotten foundations of health. Plos Med 2010; 7(11):1-9.

42. Brasil. Ministério da Saúde (MS). Pesquisa Nacional de Demografia e Saúde da Criança e da Mulher PNDS 2006: Dimensões do Processo Reprodutivo e da Saúde da Criança. Brasília: MS; 2009.

43. Thapar N, Sanderson IR. Diarrhoea in children: an interface between developing and developed countries. Lancet 2004; 363(9409):641-653.

44. Wolf J, Prüss-Ustün A, Cumming O, Bartram J, Bonjour S, Cairncross S, Clasen T, Colford JM Jr, Curtis V, De France J, Fewtrell L, Freeman MC, Gordon B, Hunter PR, Jeandron A, Johnston RB, Mäusezahl D, Mathers C, Neira M, Higgins JP. Assessing the impact of drinking water and sanitation on diarrhoeal disease in low- and middle-income settings: systematic review and meta-regression. Trop Med Int Health 2014; 19(8):928-942.

45. Pruss-Ustun A, Bartram J, Clasen T, Colford JM Jr, Cumming O, Curtis V, Bonjour S, Dangour AD, De France J, Fewtrell L, Freeman MC, Gordon B, Hunter PR, Johnston RB, Mathers C, Mäusezahl D, Medlicott K, Neira M, Stocks M, Wolf J, Cairncross S. Burden of disease from inadequate water, sanitation and hygiene in low- and middle-income settings: a retrospective analysis of data from 145 countries. Trop Med Int Health $2014 ; 19(8): 894-905$.

46. World Health Organization (WHO). UN-Water global annual assessment of sanitation and drinking-water (GLAAS) 2012 report: the challenge of extending and sustaining services. Geneva: WHO; 2012.

47. Garrett V, Ogutu P, Mabonga P, Ombeki S, Mwaki A, Aluoch G, Phelan M, Quick RE. Diarrhoea prevention in a high-risk rural Kenyan population through point-of-use chlorination, safe water storage, sanitation, and rainwater harvesting. Epidemiol Infect 2008; 136(11):1463-1471.

Article submitted 07/14/2014

Approved 09/17/2014

Final version submitted 09/23/2014 